\title{
The Effect of Patients' Characteristics and the Dosage of Methadone Maintenance on Retention of Methadone Therapy in H. Adam Malik General Hospital, Medan
}

\author{
Dian Natalya Simangunsong, Juanita, Kintoko Rochadi \\ Masters Program in Public Health, Universitas Sumatera Utara
}

\begin{abstract}
Background: The maintenance phase in methadone maintenance therapy required a long time until the patient was declared recovered, so that it often caused saturation and results in high dropout rates. Therapy retention or survival of patients in the process of therapy was one indicator of the success of this methadone therapy. This study aims to determine the effect of patient characteristics and methadone maintenance therapy dose on the retention of methadone therapy at $\mathrm{H}$. Adam Malik General Hospital Medan.

Subjects and Method: This study used a cross sectional design and was carried out at H. Adam Malik General Hospital in Medan. The number of samples in this study was the total population of 63 patients in the maintenance phase January 2017 to January 2018. The dependent variable was the retention of methadone therapy and the independent variables included age, education level, marital status, work status, domicile, and average maintenance dose even. The data in this study were obtained from the medical record data of maintenance phase methadone patients and the data analysis was done using multiple logistic regression tests.

Results: The results showed that the average maintenance dose had an effect on retention of methadone therapy $(\mathrm{OR}=5.94,95 \% \mathrm{CI} 1.06$ to $33.18, \mathrm{p}=0.042)$.

Conclusions: The maintenance dose of $\geq 60 \mathrm{mg}$ affects the retention of methadone therapy 6 times higher than the dose of $<60 \mathrm{mg}$.
\end{abstract}

Keywords: Therapy retention, patient characteristics, maintenance doses

Correspondence: Dian Natalya Simangunsong, Master's Program in Public Health of Universitas Sumatera Utara, Jl. Jahe 7 No. 14 Simalingkar A, Medan Tuntungan District, Medan, Email: dian_natalia2006@yahoo.co.id. Mobile: 0821-1133-5324

\section{BACKGROUND}

According to the United Nations Office on Drugs and Crime (UNODC) report, in 2016 there were around 275 million people (5.60\%) around the world aged $15-64$ years who had consumed drugs, 34 million of whom were Opioids drug users (UNODC, 2018).

The prevalence of drug abusers in Indonesia in 2017 was around $1.77 \%$, where the North Sumatra Province with a prevalence of drug abusers of $\mathbf{2 . 5 3 \%}$ was the province with the number two prevalence of drug abusers in Indonesia after DKI Jakarta Province (BNN, 2017).
Injectable opioids such as heroin or putaw were the types of drugs that have the greatest negative impact on health. Nonsterile use of drugs with needles and shared use were very vulnerable to transmission of HIV/AIDS so that injecting drug addicts were the group most at risk of infection with the HIV virus. There were 10.60 million injecting drug users in the world and 1.26 million of them have HIV (UNODC, 2018). The problem of HIV infection in Indonesia was closely related to unprotected sex and injecting drug use. HIV infection among injecting drug users in Indonesia ranged from 50\%-90\% (Ministry of 
Health, 2014). Another impact of injecting type drug use was to cause deaths from overdoses where according to the UNODC report $76 \%$ of drug use disorder cases were caused by injecting opioid drug use in 2015.

To anticipate the consequences of injecting drug use among drug addicts, the government made efforts through maintenance therapy activities using liquid methadone as an opiate substitute (heroin or putaw), known as the Methadone Maintenance Therapy Program (PTRM). PTRM is a form of drug substitution therapy that is replacing drugs used by drug users, which are carried out in medical supervision, with similar or similar effects but using it differrently (Kumar, 2016). The aim of methadone therapy is to reduce harm due to the use of needles when using opiate drugs, namely the risk of getting infections such as Hepatitis (B and C) and HIV (Ministry of Health, 2013).

RSUP H. Adam Malik Medan Methadone Clinic is one of the PTRM services in North Sumatra and has been established since 2008. However, the number of addict visits to the $H$. Adam Malik Hospital Methadone Clinic has decreased significantly each year and new patient visits can be said to be none. Currently, patients who are actively visiting the Methadone Clinic are patients who are in the maintenance stage. As we know that the PTRM program consists of the acceptance stage (mandatory reporting), the initiation stage, the stabilization stage, the maintenance stage, and the phase of cessation of methadone. The maintenance phase requires a long time, which can run for years until the patient's behavior is stable, both in the fields of work, emotions and social life (Ministry of Health, 2013). Because it is long-term so it often causes saturation and results in high dropout rates. At the beginning of 2017 , there were around 63 patients actively par- ticipating in therapy, but a year later the number of active patients dropped to 35 in January 2018.

Therapy retention or survival of patients in the process of therapy was one indicator of the success of this methadone therapy. Some of the results of previous studies in developed countries that there were three main categories of factors that significantly influence the retention of methadone therapy, namely program characteristics included: methadone dosage, urinalysis policy, privilege of bringing home, staff behavior, accessibility of therapeutic services, client characteristics include: age, use multi-drug, therapeutic motivation, psychological functions, and social characteristics include: family support, community support, and peer support (Sarasvita et al., 2012). Therefore, this study aims to determine the effect of patient characteristics and maintenance dose of methadone on the retention of methadone therapy at $\mathrm{H}$. Adam Malik General Hospital Medan.

\section{SUBJECTS AND METHOD}

\section{a. Study Design}

This was a cross sectional study design. The study was conducted at the Methadone Clinic at the H. Adam Malik Hospital in Medan in November 2018.

\section{b. Population and Samples}

The number of samples in this study was the total population of 63 patients in the maintenance phase for the period January 2017 to January 2018.

\section{c. Study Variables}

The dependent variable was the retention of methadone therapy and the independent variables were age, education level, marital status, work status, domicile, and average maintenance dose.

\section{d. Instruments}

The data in this study were obtained from the medical record data of maintenance 
phase methadone patients at the Methadone Clinic at $\mathrm{H}$. Adam Malik Hospital, Medan.

\section{e. Data Analysis}

The data obtained in this study were analyzed using multiple logistic regression tests.

\section{RESULTS}

Table 1 showed the frequency distribution of patient characteristics, maintenance dose and therapeutic retention during the study period. Table 1 below described the majority of patients aged $\leq 35$ years $(84.10 \%)$, moderate or high education (77.80\%), single / divorced status $(58.70 \%)$, having work or business (68.30\%), and lived in Medan City (92.10\%). Based on therapeutic factors, most maintenance patients consumed methadone with a maintenance dose averaging $<60 \mathrm{mg}(50.80 \%)$ and patients with treatment duration 365 days $(84.10 \%)$.

Table 1. Distribution of patient characteristics, maintenance dose, and therapeutic retention

Variable Total

Percentage (\%)

\section{Age}

$\leq 35$ years

$>35$ years

53

10

84.10

Education

Low

14

49

adequate/high

Marital Status

Single/divorced

Married

20

43

Working

Resident

Outside Medan

Medan

Average Maintenance Dosage

$<60 \mathrm{mg}$

$\geq 60 \mathrm{mg}$

Therapy Retention

$<365$ days

$\geq 365$ days

$\begin{array}{cc}5 & 7.90 \\ 58 & 92.10 \\ & \\ 32 & 50.80 \\ 31 & 49.20 \\ & \\ 10 & 15.90 \\ 53 & 84.10\end{array}$

provision of higher methadone doses $(\geq 60$ $\mathrm{mg}$ ) has proved important in maintaining patients in therapy. Educational level variables were not statistically proven to influence the retention of methadone therapy (OR $=3.86 \mathrm{CI} 95 \%=0.79$ to $18.62, \mathrm{p}=0.093$ ). 
Simangungson et al./ The Effect of Patients' Characteristics and the Dosage of Methadone

Table 2. The results of multivariate multiple logistic regression analysis

\begin{tabular}{lllll}
\hline \multirow{2}{*}{ Variable } & \multirow{2}{*}{ OR } & \multicolumn{2}{c}{ 95\% CI } & \multirow{2}{*}{ p } \\
\cline { 3 - 4 } & & Lower & Upper & \\
\hline Education & 3.86 & 0.79 & 18.62 & 0.093 \\
Average Maintenance Dosage & 5.94 & 1.06 & 33.18 & 0.042 \\
Constant & 0.05 & & & 0.116 \\
\hline
\end{tabular}

DISCUSSION

1. The relationship between patient characteristics and therapy retention

The results showed that most patients were $\leq 35$ years old $(84.10 \%)$. This result was in accordance with Pahlemy (2010) and Rambe (2018) which stated that the age group of respondents was mostly at the age of $\leq 35$ years old. This also in line with the results of the study which stated that the average age of patients in the study was 27.20 years old (Sarasvita et al., 2012) and 33.30 years old (Liu et al., 2009). Age of respondents was a predictor variable of methadone therapy retention (Sarasvita et al., 2012). The estimated risk of leaving therapy increased by 1.29 times in patients who were younger than 30 years old with $p=0,001$ (Huissoud et al., 2012).

Distribution of respondents based on education level that most patients have moderate/high education level (77.80\%). These results were in accordance with the results of the study which stated that the education level of the respondents of methadone maintenance therapy patients was mostly at the medium/high education level, namely high school and college (Rambe, 2018; Pahlemy, 2010; Aprilya et al., 2014; Fathollahi et al., 2016; Yang et al., 2013). Almost all methadone patients who go to the Tebet Health Center, Jakarta have higher education (Rahayu \& Syarif, 2013). The level of education contributed to the level of knowledge. The high level of knowledge was expected to increase patient motivation for routine treatment. The results of study done by Tampubolon (2012) stated that knowledge was related to the methadone patient's need to seek treatment at the PT Morawa Community Health Center Clinic in Deli Serdang District. However, in this study, no measurement was made on respondents' knowledge about methadone maintenance therapy.

The distribution of respondents was based on marital status, most of the patients were single/divorced (58.70\%). These results were in accordance with the results of the study done by Pahlemy (2010), which stated that most methadone patients treated at Jakarta RSKO and Fatmawati General Hospital in Jakarta were not married. The majority of methadone therapy patients were not married (Sarasvita et al., 2012; Liu et al., 2009). Marital status played a role in patient compliance in taking methadone therapy. Patients who live with a partner would tend to complete the therapy (Pahlemy, 2010). Most patients who routinely attend methadone maintenance therapy were patients who live with their partners (Li et al., 2019).

The results of this study indicated that the majority of patients have jobs or busyness (68.30\%) with the type of work that was mostly self-employed. This was consistent with the results of previous studies in which stated that most methadone maintenance therapy patients had work or busyness (Rambe, 2018; Pahlemy, 2010). Some methadone maintenance therapy patients have both full time and part time jobs (Liu et al., 2009; Rahayu \& Syarif, 2013). According to Ward, the occupational status 
of patients with methadone maintenance therapy is associated with greater therapy retention and better outcomes after therapy (Pahlemy, 2010).

In this study, some patients were local residents who lived in the city of Medan (92.10\%). This was in accordance with the results of a study by Liu et al. (2009) which stated that most methadone maintenance therapy patients were local residents. The patient's domicile was related to the patient's accessibility to the methadone maintenance therapy service itself. Patients who were local residents and close to therapy services tend to be easier to access services provided than patients who were not local residents. Based on the results of this study, it showed that the characteristic variables of patients in this study did not affect the retention of therapy for methadone patients. According to Ward, patient characteristics are predictors of methadone maintenance therapy retention (Pahlemy, 2010).

\section{The relationship between mainte- nance dose and therapy retention}

Based on Table 1, it showed that the majority of methadone maintenance patients have $>1$ year endurance. Retention is one of the success criteria for methadone maintenance therapy programs (Ministry of Health, 2013). Based on the results of this study, the patient retention rate for a year was $55.55 \%$ with a dropout rate of $17.46 \%$ for 3 months. The study of Vafaeinasab et al. (2015) stated that patient retention after 6 months of treatment became $28.36 \%$ and study of Rahayu \& Syarif (2013) found that the retention rate of methadone maintenance patients for 1 year of treatment was $84.60 \%$.

Based on the results of multivariat analysis with multiple logistic regression tests, it was found that the average maintenance dose had an effect on patient retention in therapy $(\mathrm{OR}=5.94 \mathrm{CI} 95 \%=1.06$ to
33.18, $\mathrm{p}=0.042)$. This mean that the average maintenance dose was a predictor of retention where the maintenance dose on average $\geq 60 \mathrm{mg}$ in this study was 5.90 times more influential on patient retention in therapy compared to the maintenance dose averaged $<60 \mathrm{mg}$. This was in accordance with the results of previous studies which stated that the provision of higher methadone doses of $\geq 60 \mathrm{mg}$ was important in maintaining patients in therapy (Sarasvita et al., 2012; Rahayu \& Syarif, 2013). Therapy retention was 1.74 times greater with methadone dosage $\geq 60 \mathrm{mg}$ compared to doses $<60 \mathrm{mg}$ (Bao et al., 2009). The daily therapeutic dose of methadone maintenance patients was a predictor of methadone maintenance therapy retention (Yang et al., 2013). Predictor variables in one year of therapy retention using the Cox proportional hazard model were high methadone doses (Fathollahi et al., 2016). According to Ward, administering a higher dose of methadone ( $\geq 60 \mathrm{mg}$ per day) was basically to prevent drug withdrawal symptoms, induce cross tolerance to the effects of heroin so that it can avoid intoxication and prevent craving against heroin (Pahlemy, 2010). A relatively larger dose of methadone was felt more appropriate to achieve the desired range of therapeutic effects, which was the effect of cross tolerance to the effects of heroin. Increasing the dose of $1 \mathrm{mg}$ of methadone gradually reduced the risk of drop out by $1 \%$ (Liu et al., 2009).

Based on the guidelines for implementing the methadone maintenance therapy program issued by the Indonesian Ministry of Health, it was stated that maintenance doses were recommended in the range of 60 to $120 \mathrm{mg}$ per day. The recommendations for dosing can be proven in this study and previous studies have stated that the maintenance dose of methadone $\geq 60$ mg has more influence on patient retention 
in methadone maintenance therapy than $<60 \mathrm{mg}$. National Institutes of Health (NIH) consensus conference guidelines for methadone maintenance therapy recommend a minimum dose of $60 \mathrm{mg}$ to achieve the best therapeutic results (Bao et al., 2009).

The maintenance dose of $\geq 60 \mathrm{mg}$ affected the retention of methadone therapy by 6 times higher than the dose of $<60$ mg. The officers at methadone maintenance therapy services pay attention to the administration of methadone doses (i.e. a dose of $\geq 60 \mathrm{mg}$ ) to get the desired therapeutic effect by the patient so that they can still keep the patient in therapy until the patient was declared recovered.

\section{AUTHOR CONTRIBUTION}

$\overline{\text { Dian Natalya Simangunsong collected data }}$ and processed data analysis. Juanita examined the conceptual framework and suggested the methodology. Kintoko Rochadi interpreted the results of data analysis.

\section{CONFLICT OF INTEREST}

There is no conflict of interest in this study.

\section{FUNDING AND SPONSORSHIP}

This study use authors personal funds.

\section{ACKNOWLEDGEMENT}

$\overline{\text { Authors would like to say thank you to } \mathrm{Me}-}$ thadone Clinic at the H. Adam Malik Hospital in Medan and those who have participated in this study.

\section{REFERENCE}

Aprilya D, Amiruddin R (2014). Hubungan faktor perilaku dengan retensi pasien program terapi rumatan metadon di puskesmas kassi-kassi (relationship between retention behavior factors and methadone maintenance therapy program at Kassi-Kassi Health Center. Uni- versitas Hasanuddin. Retrieved from https://core.ac.uk/download/pdf/254 94717.pdf.

Bao YP, Liu ZM, Epstein DH, Du C, Shi J, Lu $L$ (2009). A meta-analysis of retention in methadone maintenance by dose and dosing strategy. American Journal of Drug and Alcohol Abuse, 35(1): 28-33. https://doi.org/10.1080/009529908023 42899

BNN (2017). Survei nasional penyalahgunaan narkoba di 34 Provinsi tahun 2017 (National narcotics abuse survey in 34 provinces in 2017). In Jurnal Health. https://doi.org/10.1073/pnas.0703993104

Fathollahi MS, Torkashvand F, Najmeddin H, Rezaeian M (2016). Predictors of oneyear retention in methadone maintenance treatment (MMT) in Iran, Rafsanjan. International Journal of High Risk Behaviors and Addiction, 5(3). https://doi.org/10.5812/ijhrba.29121

Huissoud T, Rousson V, Dubois-Arber F (2012). Methadone treatments in a Swiss Region, 2001-2008: a registry-based analysis. BMC Psychiatry, 12. https://doi.org/10.1186/1471-244X-12-238

Ministry of Health (2013). Pedoman Penyelenggaraan Program Terapi Rumatan Metadona (Guidelines for Implementing the Metadona Maintenance Therapy Program). Jakarta: Kementerian Kesehatan Republik Indonesia.

Ministry of Health (2014). Gambaran umum penyalahgunaan narkoba di Indonesia (General description of drug abuse in Indonesia). Buletin Jendela Data Dan Informasi Kesehatan, Semester 1, 43.

Kumar S (2016). Methadone maintenance treatment. New York: United Nations Office on Drugs and Crime, Regional Office for South Asia. Retrieved from https://www.unodc.org/documents/so uthasia/Trainingmanuals/Methadone _Low_res_09-06-12.pdf.

Li L, Wu Z, Liang LJ, Lin C, Luo S, Cao X, Hsieh J., et al (2019). An intervention 
trial targeting methadone maintenance treatment providers to improve clients' treatment retention in China. Drug and Alcohol Dependence, 194(2018): 143150. https://doi.org/10.1016/j.drugalcdep.2018.09.021.

Liu E, Liang T, Shen L, Zhong H, Wang B, Wu Z, Detels R (2009). Correlates of methadone client retention: A prospective cohort study in Guizhou province, China. International Journal of Drug Policy, 20(4): 304-308. https://doi.org/10.1016/j.drugpo.2008.09.004.

Pahlemy H (2010). Hubungan dosis dan retensi pada terapi rumatan metadon multiepisode di Rumah Sakit Ketergantungan Obat Jakarta dan Rumah Sakit Umum Pusat Fatmawati (Relationship between dosage and retention in multiepisode methadone maintenance therapy at Jakarta Drug Addiction Hospital and Fatmawati Central Hospital). Universitas Indonesia. Retrieved from http://lib.ui.ac.id/abstrakpdf.jspdetail?id=202 92091\&lokasi=lokal.

Rahayu T, Syarif S (2013). Gambaran dan faktor-faktor yang berhubungan dengan retensi pasien program terapi rumatan metadon (PTRM) di Puskesmas Kecamatan Tebet (Overview and factors related to patient retention of the methadone maintenance therapy program at Tebet District Health Center). Retrieved from http://lib.ui.ac.id/naskahringkas/2015-09/S45733-Tri\%2oRahayu.

Rambe R (2018). Pengaruh dosis terhadap retensi pada pasien program terapi rumatan metadon fase rumatan di Rumah Sakit Umum Pusat Haji Adam Malik Medan (The effect of dosage on retention in patients of maintenance phase methadone maintenance therapy program at Haji Adam Malik Hospital Medan). Universitas Sumatera Utara. Retrieved from http://repositori.usu.ac.id/handle/123456789/3929.
Sarasvita R, Tonkin A, Utomo B, Ali R (2012). Predictive factors for treatment retention in methadone programs in Indonesia. Journal of Substance Abuse Treatment, 42(3): 239-246. https://doi.org/10.1016/j.jsat.2011.07.009.

Tampubolon DR (2012). Hubungan pengetahuan, sikap dan dukungan keluarga pengguna narkoba suntik dengan kepatuhan berobat ke klinik program terapi rumatan metadon (PTRM) di Puskesmas Tanjung Morawa Kabupaten Deli Serdang (Knowledge, attitudes and family support of injecting drug users on the compliance with treatment at the methadone maintenance therapy clinic at Tanjung Morawa Health Center Deli Serdang District). Universitas Sumatera Utara. Retrieved from https://id.123dok.com/document/8yd72x1y-hubungan-pengetahuan-sikap-dan-dukungan-keluarga-pengguna-narkoba-suntikdengan-kepatuhan-berobat-ke-klinikprogram-terapi-rumatan-metadon-ptrm-di-puskesmas-tanjung-morawa-kabupaten-deli-serdang.html.

UNODC (2018). World drug report 2018: executive summary-Conclusions and policy implications. https://doi.org/10.18356/a1062695-en.

Vafaeinasab MR, Farahzadi MH, Razaghi O M, Fallahzadeh RA. Lotfi MH, Akhondzadeh S (2015). Investigation of Affecting Factors on Persistence in the Treatment of Patients under Methadone Maintenance Therapy in Addiction Therapy Centers, Yazd-Iran. Health, 07(05): 606-616. https://doi.org/10.4236/health.2015.75072.

Yang F, Lin P, Li Y, He Q, Long Q, Fu X, Luo $Y$ (2013). Predictors of retention in community-based methadone maintenance treatment program in Pearl River Delta, China. Harm Reduction Journal, 10(1): 1. https://doi.org/10.1186/1477-7517-103 . 